\title{
Unraveling the Interplay between Inscriptions and Images: The Cosmological Mosaic of Mérida
}

\section{Yazıtlar ve Görüntüler Arasındaki Etkileşimi Çözme: Mérida Kozmolojik Mozaiği}

\author{
Anna-Laura HONIKEL*
}

(Received 02 March 2021, accepted after revision 22 August 2021)

\begin{abstract}
The cosmological mosaic in Mérida is a complex and unique pictorial creation. Due to the remarkable quality and the intricate depicted cosmological scene, the mosaic has often been the focus of research. In this paper, attention is drawn to the fact that the factors iconography and inscriptions are not always as congruous as they usually are. As a result, different associations are triggered in the recipient, which make the respective figures more multifaceted. Consequently, however, the identification and interpretation of the figures becomes more demanding.

Different modes of combining iconography and writing can be observed on the cosmological mosaic. This shall be demonstrated exemplarily with the aid of the figures Saeculum, Caelum, Chaos and Polum. Those personifications serve as a case study, since they show four different strategies of combining images and writing. It can be illustrated how variable the relationship of the iconography and inscriptions was staged and how specific intended statements were conveyed by this.
\end{abstract}

Keywords: Cosmological mosaic, Mérida, personifications, iconography, inscriptions.

Öz

Mérida kozmolojik mozaiği, karmaşık ve benzeri olmayan bir figürlü sanat eseridir. Bu döşeme, betimlenen kozmolojik sahnenin üstün kalitesi ve karmaşık niteliği dolayısıyla birçok araştırmaya konu olmuştur. Bu makalede, söz konusu mozaikte kullanılan ikonografik betimler ile bunlara eşlik eden yazıtların nasıl tutarlı olarak birbiri ile örtüşmediği tartışılmıştır. Bu durum, izleyicide farklı çağrışımlar uyandırmış ve mozaikte betimlenen figürlere çok katmanlı bir anlam yüklemişs olmalıdır. Bu tespit doğrultusunda mozaikte betimlenen figürlerin yeni bir bakış açısıyla tanımlaması ve yorumu mümkündür.

Merida kozmolojik mozaiğinde ikonografi ve yazıtların bir araya getirilmesinde farklı yöntemlerin uygulandiğı gözlemlenmiştir. Bu yöntemler, makalede Saeculum, Caelum, Chaos ve Polum personifikasyonları örneğinde tartışılacaktır. Bu personifikasyonların incelenmesi sonucunda Merida kozmolojik mozaiğinde figürler ile yazıtların bir araya getirilmesinde dört farklı yöntemin izlendiği tespit edilmiştir. Bu durum, aynı zamanda ikonografi ile yazıt arasındaki ilişkinin ne kadar değişken olabildiğini ve aktarılmak istenen mesaja göre şekillendiğini göstermektedir.

Anahtar Kelimeler: Kozmolojik mozaik, Mérida, kişileştirme, ikonografi, yazıtlar. 


\section{Introduction}

The cosmological mosaic from the Casa del Mitreo in Mérida (Fig. 1) is one of the most famous Roman mosaics in the western Mediterranean. The mosaic is dated to the late $2^{\text {nd }} /$ early $3^{\text {rd }}$ century $\mathrm{AD}$. It features a multi-figured decorative panel in which unique references are formed by the combination of the depicted personifications (Quet 1981: 22-23; Gómez Pallarès 2011: 268). However, it is not only the cosmological motive which makes this mosaic an exceptional pictorial work but also the way how it was imparted to the viewer. The complex way in which the factors iconography and inscriptions of some figures have been put in relation has attracted attention. Thereby, different modes of combining iconography and writing can be observed. In some places, iconographic elements have been assigned supposedly unsuitable inscriptions; therefore, image and text are not always as congruous as they usually are $^{1}$. As a result, tension for the viewer is created. However, exactly from this tension the actual intended statement can be extrapolated through a thorough observation and reflection by the viewer.

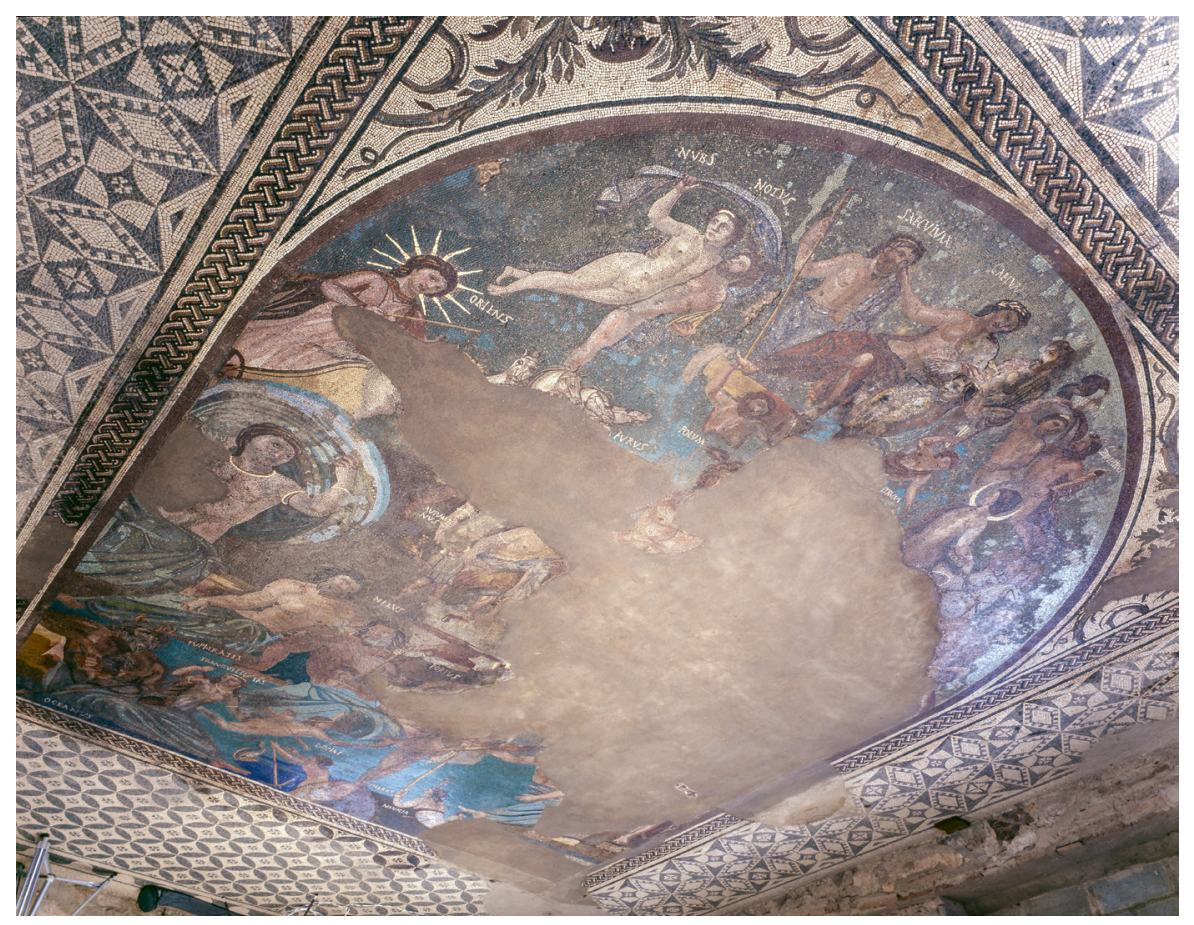

The relationship between image and writing of the personifications Saeculum, Caelum, Chaos and Polum, which have up to now mainly been investigated due to their possible philosophical or cosmological associations, shall be thoroughly analysed in this paper. The celestial group especially qualifies for a case study, since these closely connected personifications show four different modes of how image and writing have been put in relation to each other. Using this example, it is possible to demonstrate the fact that not only the interpretation of the cosmological scene but already the identification of the mythological figures was demanding.

\section{Research History}

In regard to the cosmological mosaic in Mérida, there is a high density of publications, which is mainly due to its high-quality elaboration and the

1 On this see also Honikel (in print), will presumably be published 2021 within the Madrider Mitteilungen 62.
Figure 1

Cosmological mosaic in Mérida. (C) Deutsches Archäologisches Institut Madrid, D-DAI-MAD-WIT-DMF-373, Photo: Peter Witte. 
singularity of the depicted cosmological scene. The first publication, which was published by the excavator in 1969 (García Sandoval 1969), was followed by many more over the years. Among the pivotal works are the papers by Antonio Blanco Freijeiro (Corpus España I), Elisabeth Alföldi-Rosenbaum (AlföldiRosenbaum 1979) and Janine Lancha (Lancha 1983), who have developed essential results particularly concerning technical and stylistic aspects and the chronological classification. The contribution of Marie-Henriette Quet also needs to be highlighted at this point. In her study she thoroughly analyses the possible philosophical meaning and cultural backgrounds of the cosmological mosaic (Quet 1981)2.

Anyhow, the more 'traditional' issues of mosaic research, as for example a thorough iconographic analysis of the figures, faded into the background, since the complexity of the motive and the connected question of interpretation had highly stimulated the archaeological research. Of particular interest were the decoding and interpretation of the possible philosophical or cosmological backgrounds of the figural panel. To approach this endeavor, research has concentrated on a few supposed key figures on the mosaic. In order to analyze these and to decipher their references, research has often worked with ancient written sources. Many different interpretive approaches were developed from these analyses ${ }^{3}$.

However, the uneven distribution of research interest has led to personifications such as Saeculum or Aeternitas being examined in much more detail than the majority of the figures on the mosaic, which received significantly less scholarly attention. Therefore, there is only a short description of Chaos, for example, but no thorough iconographic or interpretive analysis.

The want of a careful iconographic analysis also means that it has not yet been researched how the factors iconography and inscription were put into relation to one another and how the intended statement could be conveyed from this. This is to be changed in this contribution. Here the previous approach is reversed, and the iconography and inscription of the figures come into focus. With the aid of four personifications on the cosmological mosaic, the complex interplay between iconography and inscription is examined and it can be shown how differently both factors were staged.

\section{The Cosmological Mosaic in Detail}

The cosmological mosaic is 8.09 x $5.92 \mathrm{~m}$ large and has mainly been laid with tesserae from limestone, quartzite and glass paste using the techniques of opus tessellatum and opus vermiculatum. Unfortunately, the mosaic is considerably damaged. As the result of a fire, the tesserae, especially those in the upper part of the mosaic, have in part darkened irreversibly and due to various defects, approximately one third of the decorative panel is lost (Corpus España I: 22. 36; Alföldi-Rosenbaum 1979: 27-31) ${ }^{4}$.

The cosmological scene is clearly structured and can be divided into three compositional levels: maritime, terrestrial and celestial. The mythological figures who can be found in the respective levels naturally belong into the depicted environment.

2 On the cosmological mosaic see among others also Alföldi 1979; Musso 1983/4; Fernández-Galiano 1990; Alföldi-Rosenbaum 1993; Arce 1996; Gómez Pallarès 2011

3 On the different interpretive approaches see among others Blanco Freijeiro 1971: 175-178; Alföldi 1979; Quet 1981: 51-72, 187-196; Fernández-Galiano 1990; Arce 1996: 102-106, 109-110.

4 For all restauration measures in detail and the materials used see Lancha 1983: 18-30, 31-37. 
In the left corner of the maritime level (Fig. 2) lies Oceanus with his characteristic pincers growing from his head. As further attributes, he carries a spear, a sea serpent and a conch shell horn. In contrast to most other figures, his carnation is very dark. The naked but richly adorned Tranquillitas emerges from behind him. Beside them swims the personification of abundance and plethora, Copiae. She is steered like a ship by a rowing boy sitting on her back. Her outstretched hand holds a cornucopia and on her head sits a diadem which ends in an extension in the form of a ship's bow. Below her is another female figure who holds an anchor in her outstretched hand. This figure does not have an inscription of her own. On the one hand, it is possible that the respective name inscription is not preserved $^{5}$. On the other hand, it is also thinkable that this female figure belongs to the inscription Copiae as well, since this term is given in plural and might thereby also be used for two figures ${ }^{6}$. Pharus appears as a naked young man who stands on a rock holding a burning torch. Navigia is depicted similar to Copiae. She also wears a diadem in the form of a ship's bow and is steered by a rowing boy. As an additional attribute, she holds a sailing mast ${ }^{7}$. In the right corner, there are three heavily fragmented figures. Only the inscription of the figure at the edge of the decorative panel is preserved; its left lower leg belongs to the personification of Pontus.
Figure 2

Maritime level of the cosmological mosaic.

(C) Deutsches Archäologisches Institut Madrid, D-DAI-MAD-WIT-DMF-377, Photo: Peter Witte.

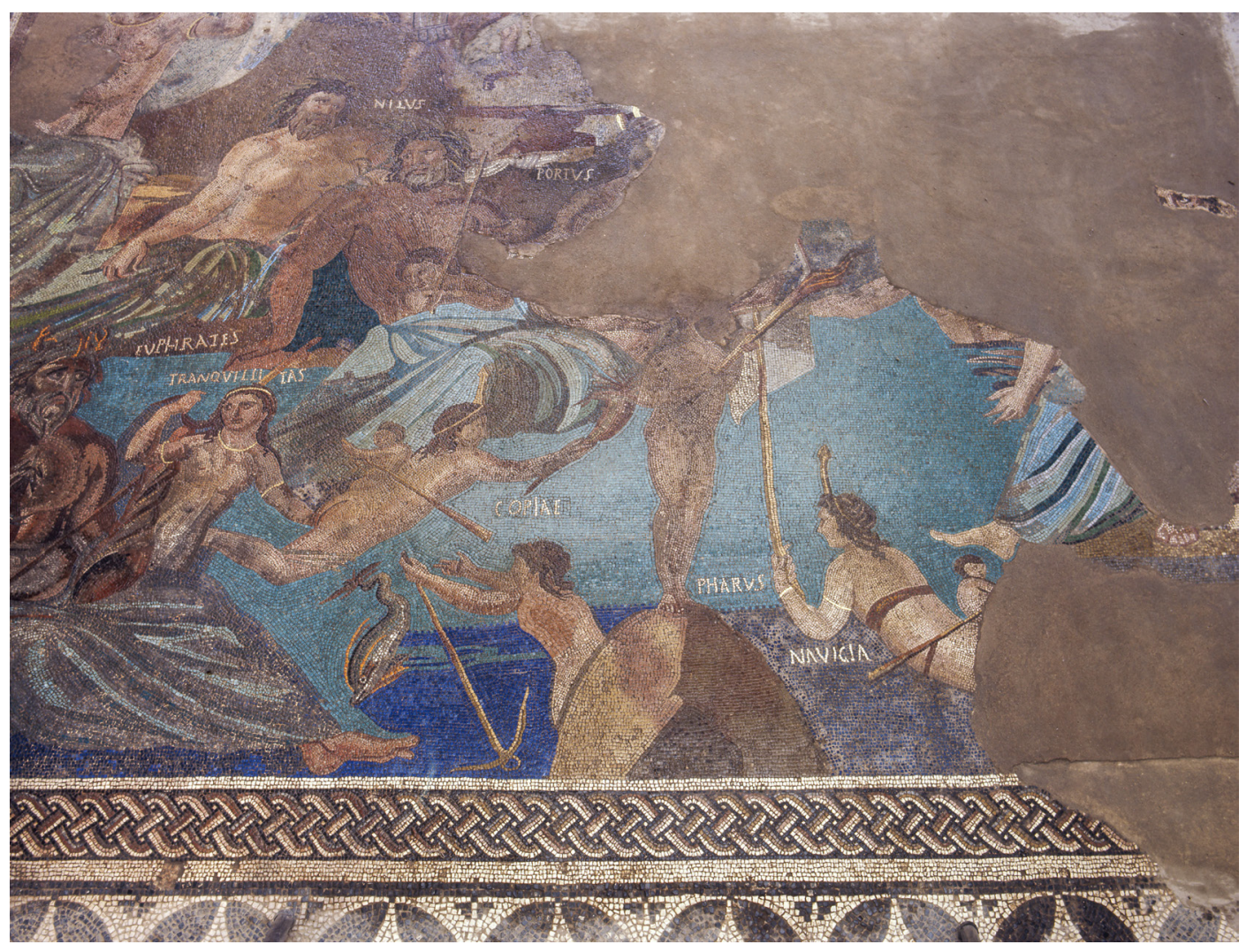

5 Parts of the mosaic's background around this figure had to be restored in modern times, since they were only badly preserved (Alföldi-Rosenbaum 1979: 30 fig. 4.).

6 The term Copiae as name for a personification is irritating because in general, the base form of the noun which is to be personified is used. A personification with the name Copiae is unknown in antique written sources, and apparently there are no further images of this figure. In contrast, coins featuring a mythological figure with the legend Copia are documented. From a linguistic point of view, the usage of the plural Copiae is also far less common in Latin sources than the base form Copia. This is why it is indeed imaginable that here the unusual plural form of the inscription names two figures. On the personification of Copia see Hernández Iñiguez 1986a: 304. On Copiae see Hernández Iñiguez 1986b: 305 .

7 As is the case with the inscription Copiae, Navigia also seems to have been put in plural (Quet 1981: 25). 
In the middle, terrestrial level (Fig. 3) sits Natura, whose velum flutters up behind her. Beside her are the lying river deities Euphrates and Nilus, both wearing wreaths of reed on their heads. Euphrates holds a jug from which water is flowing out and a boy with a sailing mast in his hand sits on Nilus' lap. The figure Portus is hardly preserved; all that is left is a part of the head with a mural crown and parts of the upper body. Beside Natura's velum are the seasons Autumnus and Aestas carrying their usual attributes; they are about to walk through the zodiac

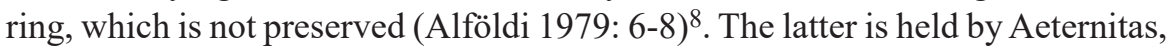
who inhabits the central position on the mosaic. Only the naked muscular upper body and the head with a head wing is preserved from the personification of eternity 9 . The large defect around Aeternitas continues all the way to the bearded Mons, who is depicted at the outer edge of the decorative field. The sleeping figure Nix - snow - lies on the lap of the personification of the mountains.

Figure 3

Terrestrial level of the cosmological mosaic. (C) Deutsches Archäologisches Institut Madrid, D-DAI-MAD-WIT-DMF-378, Photo: Peter Witte.

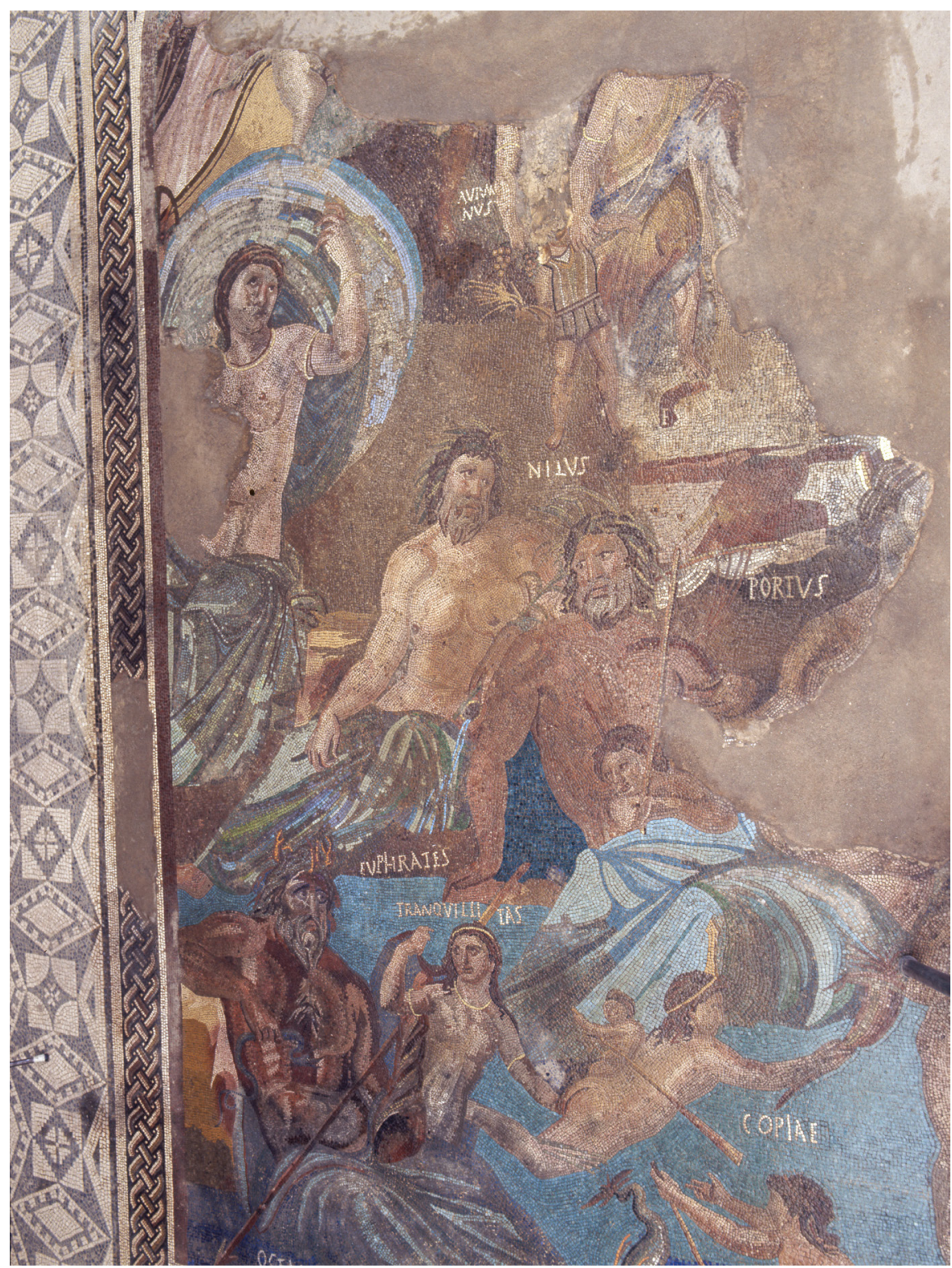

8 For an iconographic parallel see the Aion mosaic from Silin, in situ (?) (AD 150-200) (Dunbabin 1999: 122-123).

9 Contrary to custom, the personification Aeternitas is depicted as a male figure corresponding to the iconography of Aion. See also Honikel (in print). 
In the uppermost, celestial level of the mosaic (Fig. 4), Oriens guides his quadriga. $\mathrm{He}$ is dressed in the usual garb of a charioteer, and an aureola is featured around his head. In front of Oriens' white horses flies the wind god Eurus, from whom only the left lower leg and the inscription are preserved ${ }^{10}$. Above the quadriga, Nubs and Notus hover together, while Nubs' cloak bulges above both of them. Directly beneath the apex of the semi-circular border of the figural panel, the three personifications Saeculum, Caelum and Chaos are sitting enthroned. The god of the sky has put his feet on a platform which is supported by Polum. A figure whose inscription is not preserved has their right arm entwined around the leg of Caelum's throne, the left is raised above the head. The figure's gender cannot be determined without a doubt, although it is possibly to be interpreted as female due to the manner of representation ${ }^{11}$. Beside the unknown figure, Tonitrum is hurling a thunderbolt. Like Nubs and Notus, Nebula and Zephyrus are depicted hovering. Below them, Occasus is riding a biga. A crescent moon is featured around the head of this personification. At the right border of the figural panel, the wind god Boreas is depicted.

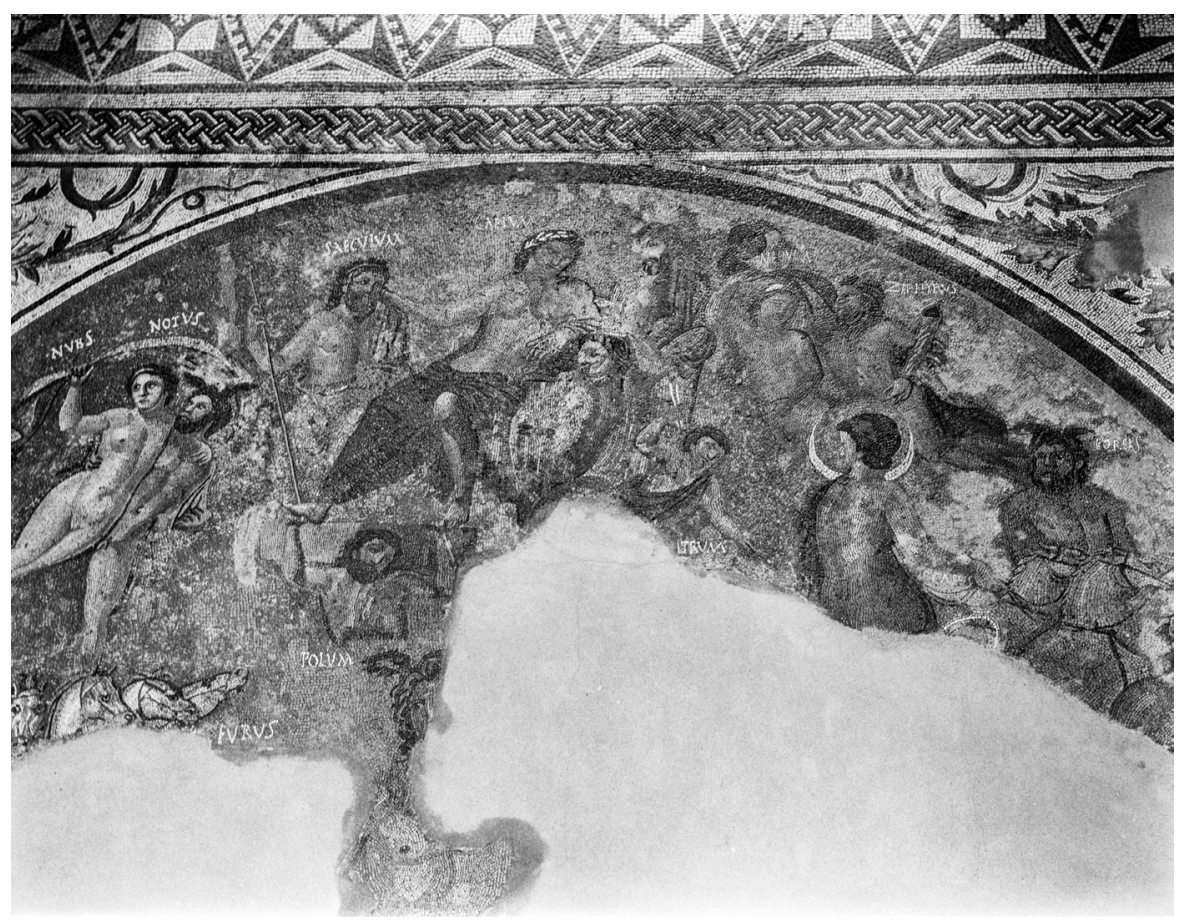

10 For a possible reconstruction of Eurus see Alföldi 1979: 8 fig. 1.

11 Various defects as a result of a fire and the missing piece beneath the figure complicate the identification of the gender. Since the lower body cannot be seen and particularising attributes are missing, only the upper body and the hair style can be adduced. The curvy arrangement of the tesserae in the chest region is noticeable, although does not necessarily speak for a female figure. Such an emphasis on the chest can be found on the mosaic both in female and male figures - for example in Natura, Portus or Caelum. The hair style however - carefully coiffured out of the face-mostly corresponds to the one of Nubs or Occasus. Because of this, a female interpretation of the unknown figure suggests itself. Archaeological research has also dealt with the gender and the identity of this figure. Blanco Freijeiro (Corpus España I: 37) supposes that it could be the goddess of night, Nox. He reasons with the similarity between the unknown figure on the mosaic and the representation of Nox on an imperial frieze sarcophagus. However, both depictions differ considerably. By contrast, Alföldi (1979: 4) thinks this figure is to be identified as Aether. The only (unverified) depiction of Aether on the south frieze of the Pergamon Altar does not exhibit any similarities to the figure on the cosmological mosaic either. Nox and Aether as celestial deities surely suit the other mythological figures in the immediate compositional proximity - but neither Nox nor Aether show any significant iconographic congruity to the representation of the figure in Mérida.
Figure 4

Celestial level of the cosmological mosaic.

(C) Deutsches Archäologisches Institut Madrid, D-DAI-MAD-WIT-R-45-76-02, Photo: Peter Witte. 


\section{Relationships Between Image and Writing}

As can be seen, the large number of mythological figures leads to a great complexity of the decorative field and the cosmological motive. Personifications - that is, anthropomorphic impersonations of abstract nouns - can become identifiable by means of their form of representation (attributes, iconographic conventions or context). Additionally, inscriptions can also take part in the identification $^{12}$.

At this point it should be mentioned that the determination of a personification with the aid of inscriptions is only seemingly unambiguous. As has already been introduced briefly, the relationship between the depicted figures and the respective (name) inscriptions is complex and, in some cases, needs a more thorough observation. This is especially true in cases where image and writing are not completely congruent. Discrepancies of that kind have nevertheless up to now been hardly considered in research, although relationships between image and writing play an important role in pictorial sciences. However, there are some publications which deal with the relationship between image and writing in general ${ }^{13}$. The factors image and writing particularly on mosaics have only been investigated recently 14

Induced by the partly tension-filled interaction of pictorial schemes and associated inscriptions on the cosmological mosaic, the viewer is coerced to deal with the individual figures more intensively. Both the iconography and the inscriptions evoke certain associations which need to be put in order, evaluated and correlated. These associations help in relieving the initial irritation, which is felt by the viewer due to a seeming contradiction of iconography and text, and in deducing the intended statement. The images and inscriptions on the cosmological mosaic can be connected to certain mythological figures or to actual cosmic or natural phenomena. What exactly the recipient might originally have associated with the depictions or the writing can of course not be reconstructed with certainty and will have depended on individual and personal experiences (Borg 2002: 70). However, the preoccupation with the decorative panel certainly encourages a reflection on what is perceived, what is already known and what it can be connected to.

Below, it shall be demonstrated exemplarily with the aid of the personifications Saeculum, Caelum, Chaos and Polum how variable the relationship of the iconography and inscriptions was staged and how specific intended statements were conveyed by this.

\section{Iconographic Analysis of the Celestial Group}

Research has up to now approached these personifications mainly starting from the inscriptions. Furthermore, the focus was often on determining which cosmological or philosophical ideas might be best to associate them with. Parallels for the associations connected to the inscriptions were searched in other pictorial

12 Referring to pictorial personifications. For details see Borg 2002: 82; Meyer 2007: 184-186, 191; Weil 2005: 79.

13 Examples for this from recent years: see among others Newby - Leader-Newby 2007; Squire 2009; Beltrán Lloris et al. 2017. On relationships between image and writing in general also Elsner 1996; Rutter - Sparkes 2000; Giuliani 2003.

14 For this see for example Notermans 2007, who has published an extensive collection of material on this topic. Gómez Pallarès (2011: 263-278) and Mayer (2004: 109-125) deal with a focus on Hispanic mosaics. For a comprehensive systematic analysis of the relationships between image and writing on mosaics of the $3^{\text {rd }}-5^{\text {th }}$ centuries AD see Schmieder (in print); it will presumably be published in 2021 within the series Materiale Textkulturen (Heidelberg). 
works, ancient myths or written sources. Thereby, attempts to put the celestial group into a certain context partly led to highly complex interpretations ${ }^{15}$.

The iconography of the personifications faded into the background. Thus, this is an attempt to approach the figures from another angle and to first work out the references created by the combination of iconography and inscription. Only on this basis and in a second step it will be possible to deduce deeper levels of meaning and to pursue possible cosmological explanation attempts.

Saeculum: The first figure of the celestial group, which is named Saeculum by the inscription, is dressed in a blue cloak (Fig. 5). He is in a sitting position and turns slightly to the right while he looks at Caelum who is enthroned in the middle. Saeculum has long hair, a full beard and wears a diadem on his head. With the right hand, he holds a sceptre which is propped on the podium supported by Polum.

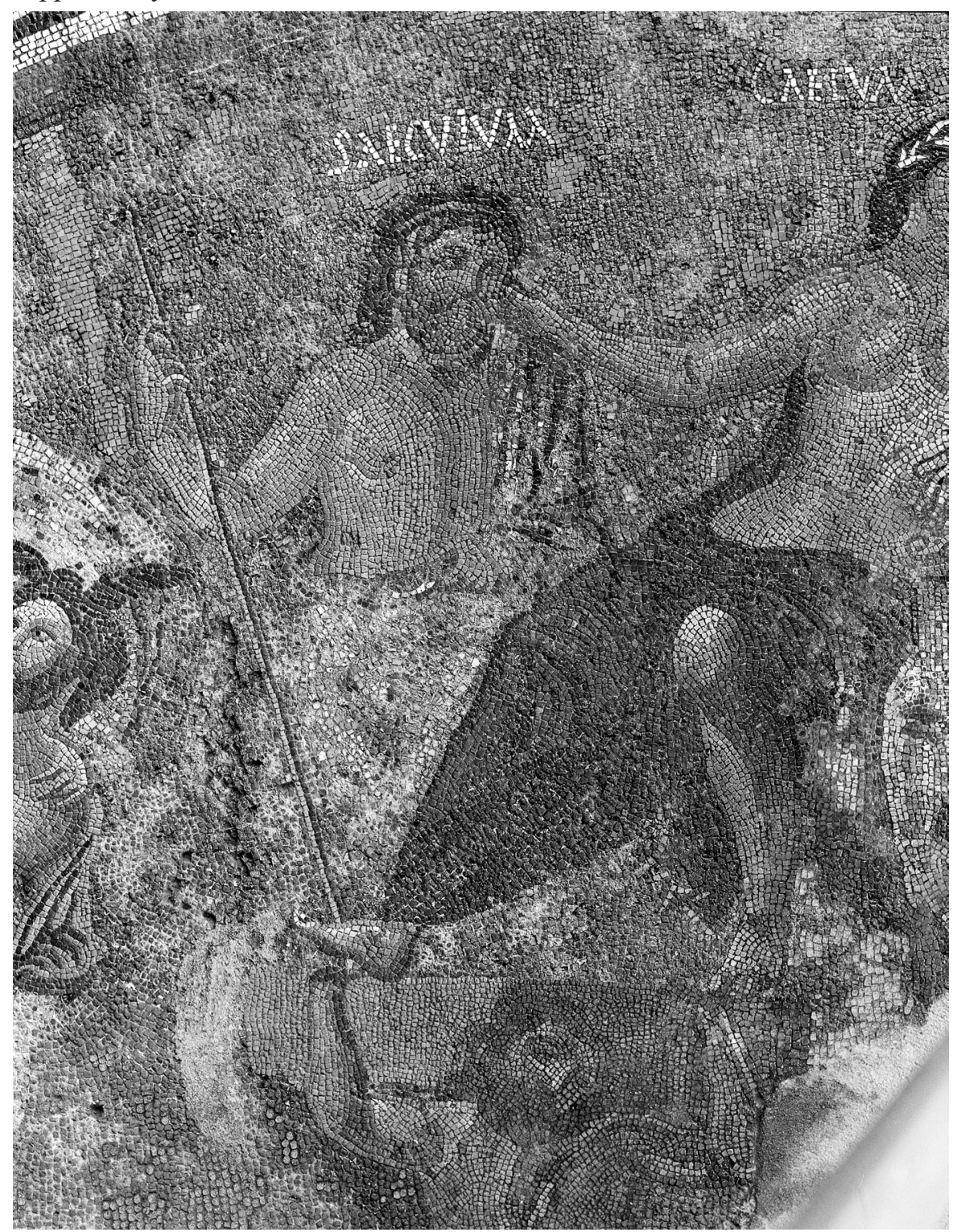

Verified comparisons of a personification with the designation Saeculum can exclusively be found on Roman coins (López Monteagudo 1997: 1071-1072). Nevertheless, they hardly share iconographic equivalents with the figure of
Figure 5

Detail of the personification Saeculum on the cosmological mosaic.

(C) Deutsches Archäologisches Institut Madrid, D-DAI-MAD-WIT-R-105-78-12, Photo: Peter Witte. 
Figure 6

Saeculum Frugiferum with trident and winged caduceus, American Numismatic Society. (C) American Numismatic Society.

Figure 7

Enthroned Saeculum Frugiferum, Münzkabinett der Staatlichen Museen zu Berlin. (C) Münzkabinett der Staatlichen Museen zu Berlin, 18203717. Photo: LutzJürgen Lübke (Lübke und Wiedemann).

Saeculum on the cosmological mosaic. On some coins, the standing Saeculum appears without a beard and with an aureola. He is dressed in a cloak which he has draped loosely around his hips. In his left hand, he holds a trident, in his right hand a winged caduceus (Fig. 6) ${ }^{16}$. On other coins, however, he appears with a full beard and is enthroned between two sphinges. He wears a long garment and a modius on his head. In his left hand, he holds ears of grain (Fig. 7) ${ }^{17}$. This is a representation which corresponds to the Punic fertility god Ba'al Hammon ${ }^{18}$. Although the manners of representation on the coins differ, both are labelled Saeculum Frugiferum on the legends. Therefore, the personification of the age of fertility is depicted (López Monteagudo 1997: 1072-1073; Heckel 2002: 707708).
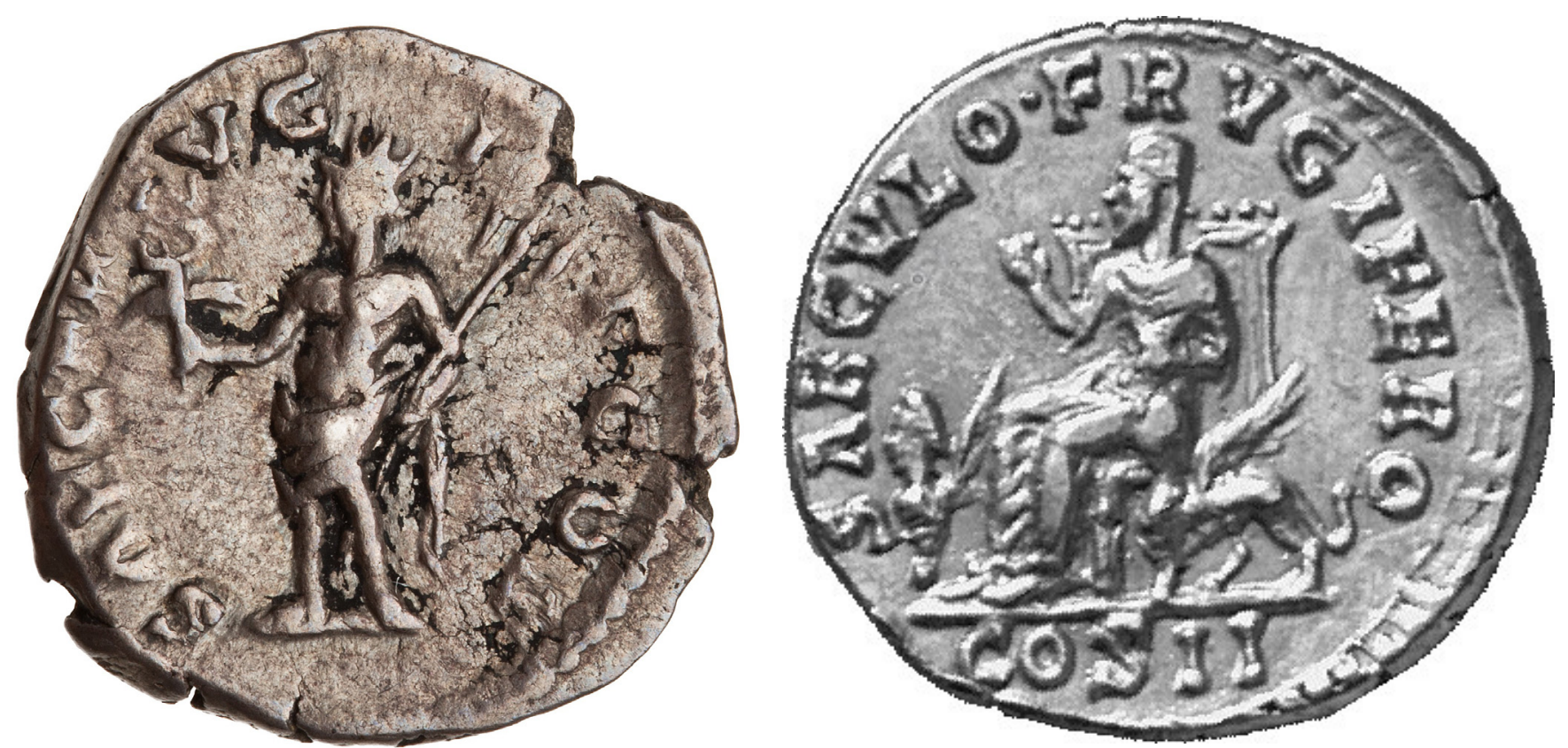

Another comparison to a mythological figure with the designation Saeculum can be found on aurei of Hadrian. On the reverse images, a beardless male figure is standing amidst the Zodiakos. He holds a globe in his left hand with a phoenix sitting on top of it (Fig. 8) ${ }^{19}$. The legend designates him as Saeculum Aureum, thus the personified Golden $\mathrm{Age}^{20}$. Both the personification of the age of fertility and the one of the Golden Age are thematically suitable for the established repertoire of coinage, for they imply that exactly these ideal times exist during the reign of the emperor. Personifications on coins often visualise virtues of the emperor, political tendencies or promises and were therefore a popular medium of propaganda and the imperial self-representation (Weil 2005: 79).

16 Saeculum Frugiferum with trident and caduceus on an as (AD 194-195): RIC IV Clodius Albinus $61 \mathrm{~A}$.

17 Saeculum Frugiferum enthroned on an aureus (AD 194-195): RIC IV Clodius Albinus 10.

18 See for example the figurine of Ba'al Hammon from Thinissut, Musée National du Bardo ( $1^{\text {st }}$ century AD) (Driss 1966: 12-13). For the similarity between some representations of Saeculum Frugiferum to those of Ba'al Hammon see Bonacasa Sáez 2014: 455-457.

19 Saeculum Aureum with Zodiakos, globe and phoenix on aurei (AD 119-122): RIC II Hadrian 297.

20 In literature, the figure is also interpreted as the genius of the Golden Age or as Aion (Le Glay 1981: 404). The interpretation as Aion probably derives from the Zodiakos, which is held by Aion on numerous depictions (see for example the so-called Tellus mosaic from Sentinum, Glyptothek München, Gl 504 (ca. AD 200) (Wünsche 2005: 164; Şahin 2009: 98). However, the characteristic head wings of Aion are missing on the coin and the attributes globe and phoenix also seem quite unfamiliar in this context. 


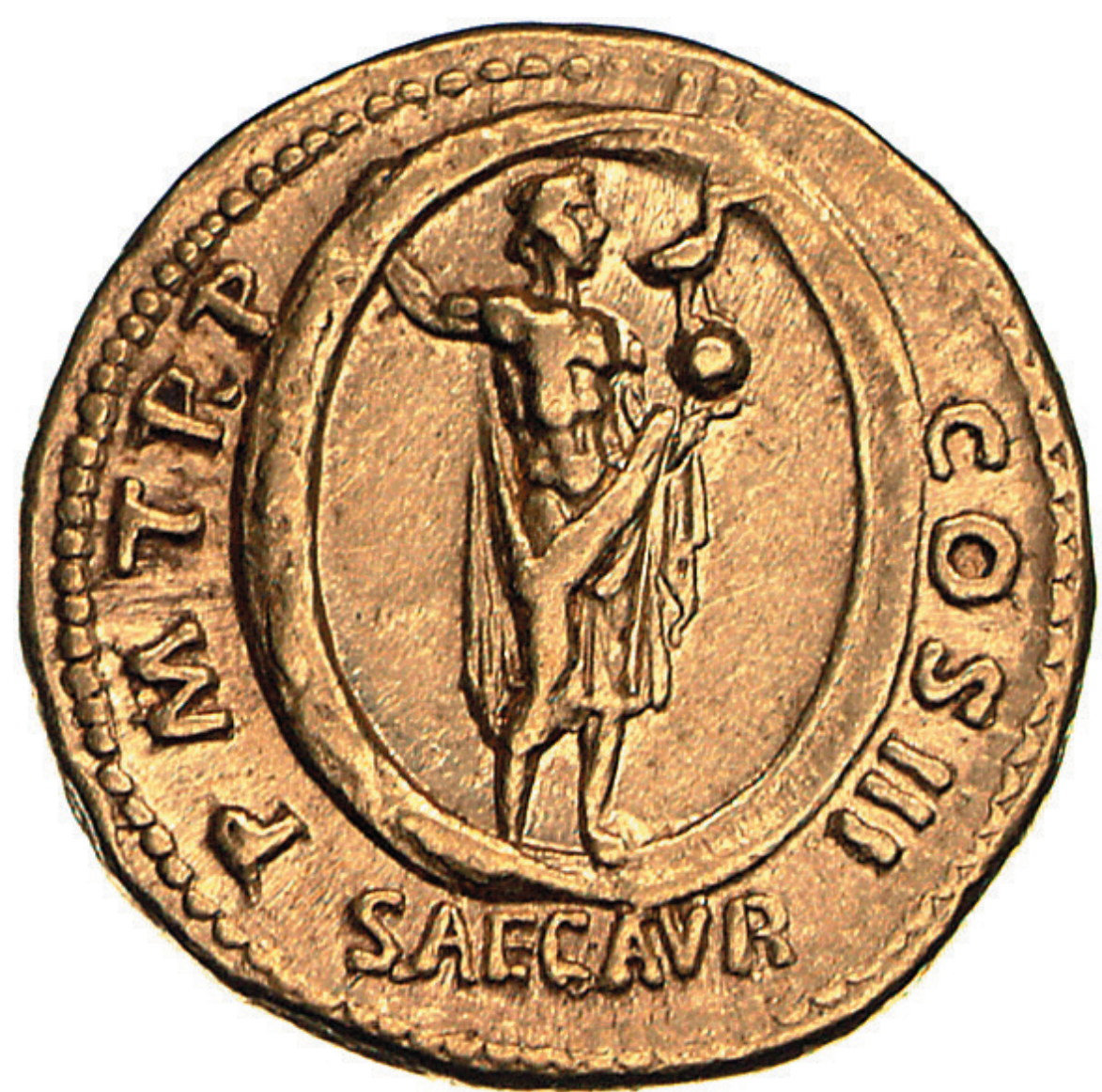

This now raises the question which specific manifestation of Saeculum is meant on the cosmological mosaic. The personification Saeculum, who we otherwise only know in combination with an epithet, embodies two different meanings and possesses three different determined pictorial schemes. The figure of Saeculum on the cosmological mosaic mostly corresponds to the iconography of the enthroned Saeculum Frugiferum/Ba'al Hammon ${ }^{21}$. Nevertheless, the personification on the mosaic appears without the particularising attributes modius, sphinges and ears of grain, which have been substituted by the nonspecific attributes diadem and sceptre. Thereby, this generic manner of representation only reminds of very common father gods which the antique viewer could connect to several different deities, like for example Zeus, Poseidon or Asklepios ${ }^{22}$. The 'sitting enthroned' and the attributes diadem and sceptre are also quite unspecific, since they can appear in a number of (father) gods.

The inscription Saeculum on the mosaic appears, as far as it is known, for the first and only time without the particularising epithets frugiferum or aureum. This means that not only the iconography but also the inscription has been generalised. Due to this twofold generalisation, the figure might at first appear unspecific. However, the viewer was able to deduce the intended statement exactly because of it: the generalised factors image and writing imply a disengagement from the
Figure 8

Saeculum Aureum with Zodiakos, globe and phoenix, Münzkabinett der Staatlichen Museen zu Berlin. (C) Münzkabinett der Staatlichen Museen zu Berlin, 18204693. Photo: D. Sonnenwald.

21 Blanco Freijeiro supposes that the way of representation of Saeculum is inspired by the iconography of the deities Jupiter and Pluton-Serapis (Blanco Freijeiro 1971: 158-159; Corpus España I: 22). By contrast, Alföldi (1979: 2-3. 5) compares the iconography of Saeculum to that of Kronos-Saturnus, Zeus, or Baal. However, neither Blanco Freijeiro nor Alföldi quote any iconographic parallels. Alföldi-Rosenbaum (1993: 258) sees similarities between the iconography of Saeculum and that of Jupiter-Caelus, Jupiter-Aion from the Villa Albani, or Aion on the mosaic from Nea Paphos.

22 On the iconography of father deities see for example Thiemann 1959. 
Figure 9

Detail of the personifications Caelum and

Chaos on the cosmological mosaic.

(C) Deutsches Archäologisches Institut

Madrid, D-DAI-MAD-WIT-R-18-75-07,

Photo: Peter Witte.

established associations and at the same time a reduction to the basic meaning of the term saeculum. This would mean that here the personified age or saeculum was depicted ${ }^{23}$. A saeculum constitutes a period of 100 or respectively 110 years.

Caelum: Beneath the apex of the semi-circular edge of the figural field, a figure named Caelum (Tam Tinh 1994: 132-136) sits enthroned between Saeculum and Chaos (Fig. 9). He wears a wreath on his beardless head and is dressed in a red cloak which has slid down to his lap and reveals his upper body. His posture is relaxed: he leans back, his left arm is supported by the armrest. The right hand rests on Saeculum's shoulder and his feet are loosely propped up on the platform which is supported by Polum.

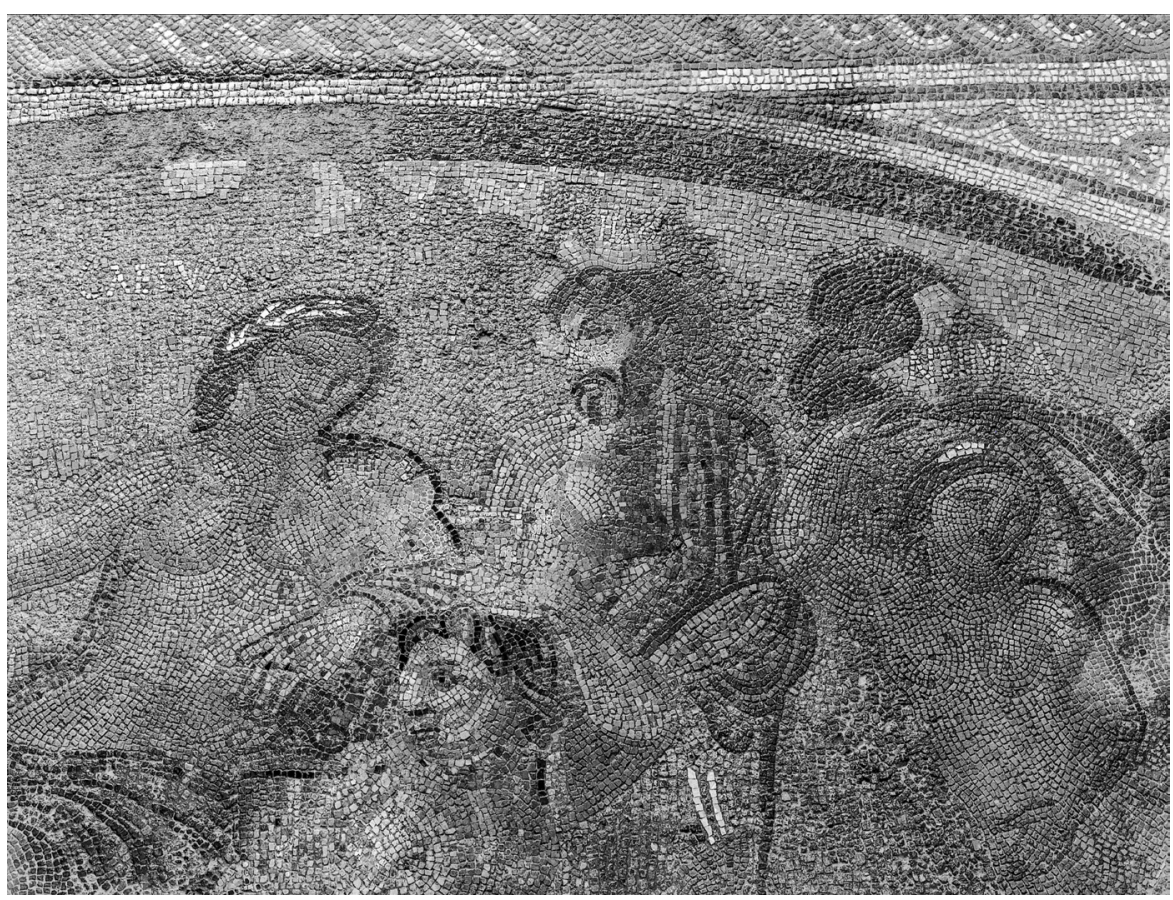

Iconographic parallels for the sky god can be found on different media. There, he is depicted with a cloak which billows out over his head and is probably meant to indicate the vault of the sky (Tam Tinh 1994: 135). Usually, he is featured from the upper body up, undressed and bearded (Fig. 10) ${ }^{24}$. There are also parallels on Roman sarcophagi where he appears with the characteristic cloak, albeit younger, that is, beardless. However, such depictions are far less common ${ }^{25}$. As can be seen, Caelum possesses a determined iconographic convention including a particularising attribute without which he never appears. The Greek pendant of Caelum, Ouranos, also conforms to this convention (Tam Tinh 1994: 133).

23 In research, the figure Saeculum has so far been interpreted differently. Blanco Freijeiro connects the personification with the orphic cosmogony and equates Saeculum with the Greek god Chronos. In connection with this, he identifies the enthroned personifications next to Saeculum as his sons Aither (Caelum) and Chaos. Alföldi (1979: 4-5) assumes that the figure could be the personified Saeculum Aureum. Quet (1981: 96-100) disagrees by emphasising that neither the way of representation nor the inscription suggest an interpretation as Saeculum Aureum. She interprets Saeculum as a personification of the beginning of a new universe in the context of stoic philosophy and draws her analysis on iconographic parallels and written sources.

24 On this, see for example: Caelum on the cuirassed statue of Augustus of Prima Porta, Musei Vaticani Rome, 2290 (ca. AD 20) (Montiel Alvarez 2015: 127-133); Caelum on a Roman frieze sarcophagus from Amalfi, DAI Rom, 65.1213 (first half of the $2^{\text {nd }}$ century AD) (Sichtermann 1992: 90).

25 On this, see for example beardless Caelum on a Roman sarcophagus, Museo Archeologico Nazionale Naples, 6705 (ca. AD 300) (Sichtermann- Koch 1975: 62-63). For further parallels see Tam Tinh 1994: 134 


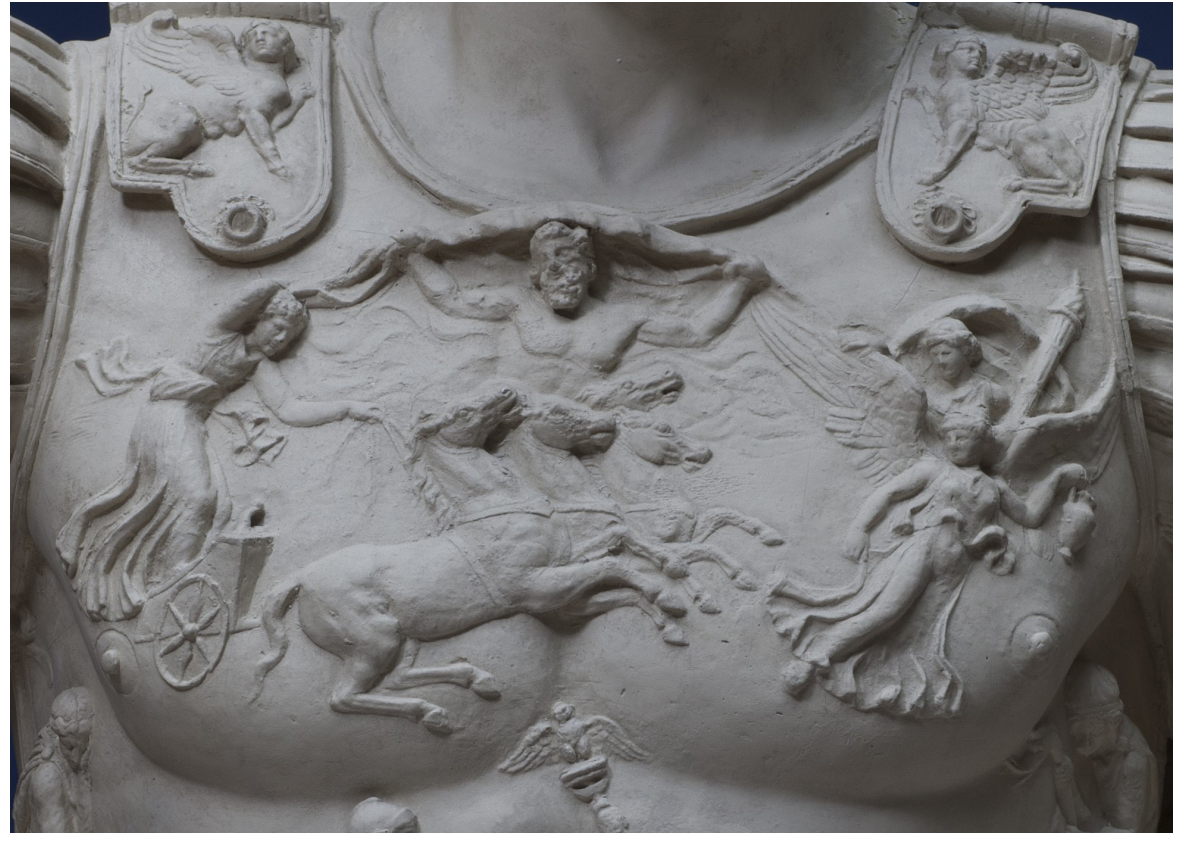

The depiction of Caelum on the cosmological mosaic differs fundamentally from his usual way of representation. The figures are of a different age (beardless/full beard), posture and motive differ distinctly (leaned back and enthroned, hand loosely put on Saeculum/holding his cloak over his head with raised arms) and the particularising attribute was substituted with an unspecific wreath. Due to the generalisation of the iconography of Caelum, he can no longer be identified by means of his form of representation alone. On the basis of his youthful appearance and his relaxed posture while sitting enthroned, Caelum could have instead been connected to other mythological figures, like for example Dionysos ${ }^{26}$.

Without the inscription, the viewer had hardly been able to explicitly identify this personification on the cosmological mosaic ${ }^{27}$. Whereas the inscription Caelum is also quite common, it is far less frequent than the usually used form Caelus (Blanco Freijeiro 1971: 156) ${ }^{28}$. Nevertheless, it clearly refers to the sky god ${ }^{29}$. The generalisation of the iconography suggests that the personification Caelum in Mérida is pictorially clearly set off against the personification to which the inscription is usually connected.

Chaos: The third figure of the enthroned trio, named Chaos by the inscription, has a full beard and is dressed with a cloak which he has pulled over the back of his head (see Fig. 9). Parts of his upper body remain uncovered. His face with clearly accentuated brows is turned in the direction of Caelum, who is sitting to his right. Since Chaos' lower body is covered by other personifications, it is

26 On this, see for example depictions of Dionysos on the Villa of the Mysteries frieze in Pompeii or on the Aldobrandini Wedding in Rome (Davis 2000: 84-85. 89-93; Müller 2019). The similarity to Dionysos was also pointed out by other scholars (Alföldi 1979: 4; Quet 1981: 89).

27 However, after the identification, Caelum's positioning becomes more prominent. Possibly, the god sitting enthroned beneath the semi-circular border of the decorative panel, which arches over him, is meant as reference to his fluttering cloak. Such a conclusion could only have been drawn by the viewer after he had consulted the inscription for an identification.

28 On pictorial media, the inscription seems to be testified only once. However, the inscription C(A)ELUM on a Mithras stele from Nida-Heddernheim does not refer to a personification but to the depiction of a lightning-carrying eagle sitting on a celestial sphere (CIMRM 1127; Huld-Zetsche 1986: 72).

29 In contrast to this identification, Alföldi interprets Caelum as a personification of eternity and the well-ordered state of the cosmos. Furthermore, he and later also Alföldi-Rosenbaum point out that both Saeculum and Caelum would show different aspects of eternity or rather of the god Aion (Alföldi 1979: 3-5; Alföldi-Rosenbaum 1993: 259).
Figure 10

Detail of Caelum on the cuirass of Augustus Prima Porta, Museum für Abgüsse

Klassischer Bildwerke München, Inv. 274.

(C) Museum für Abgüsse Klassischer

Bildwerke München, Abguss Inv. 274.

Photo: Roy Hessing (Detail). 


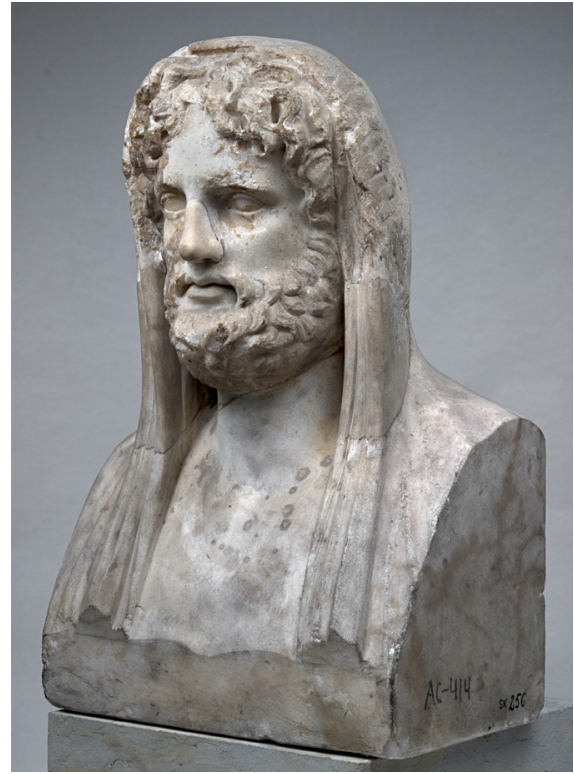

Figure 11

Bust of the god Saturn, Staatliche Museen zu Berlin, Inv. Sk 256.

(C) Staatliche Museen zu Berlin, Antikensammlung, Inv. Sk 256. Foto: Universität zu Köln, Archäologisches Institut, CoDArchLab, 105701,01 FASPerg-000044-02_Philipp Groß. Photo: Philipp Groß. not possible to determine if he is depicted standing or sitting down. However, due to the fact that his head is on the same level as the heads of the sitting figures Saeculum and Caelum, it can be assumed that he is also enthroned. Other pictorial sources of this mythological figure are not known (Cruz Fernández Castro 1986: 189).

The iconography of Chaos is similar to the one of Saturn, who is usually also depicted bearded and with his cloak pulled over the back of his head (Fig. 11) ${ }^{30}$. The established attribute of Saturn, his harpe, has not been featured on the cosmological mosaic, however. Saturn, one of the oldest deities of Rome, is characterised by his functional diversity. Due to his identification with the Greek Kronos, he, too, is to be understood as the god of sowing and agriculture. At the same time, he, like his Greek pendant, is connected to the Golden Age which he is supposed to have ruled over. In addition, the connection to these paradisiac times gives him a temporal and a cosmic character (Baratte 1997: 1078; Baudy 1999: 864-869; Heckel 2002: 707-708).

However, the inscription unambiguously names the personification on the mosaic as Chaos, who has been described as an original deity by Hesiod. Connected to cosmogony, he is designated as the void from which everything else has originated - the primordial state (Hes. theog. 116-12531; Kirk 1994: 3840). Therefore, Chaos and Saturn share a semantic overlap, since both possess distinct cosmic and temporal references. Since the figure on the cosmological mosaic seems to be a newly introduced pictorial creation whose iconography can be associated with Saturn by the cloak pulled over the back of the head, the inscription in this case constitutes an indispensable factor for the identification ${ }^{32}$.

Polum: The figure designated as Polum by the inscription is featured from the naked upper body upwards. He is fully bearded and carries the platform on his shoulders on which the above-described figures are sitting enthroned (Fig. 12). As was the case with Chaos, there seem to be no further preserved images of a personification with the name Polum. Yet obvious parallels can be found in the iconography of Atlas. Above all else, the motive of supporting or carrying reminds of the Titan carrying the celestial sphere ${ }^{33}$.

Here, only the inscription serves for the required differentiation and was therefore essential for the identification of the figure Polum. The grammatical gender of the term is conspicuous: instead of using one of the common designations polus or polos $(\pi$ ó $\lambda \mathrm{\sigma} \varsigma)$, the otherwise not attested form polum was featured on the cosmological mosaic (Alföldi 1979: 4; Quet 1981: 22). Thereby, even two personifications of the celestial group who usually carry the ending -us are now ending in -um. In contrast to Polum, however, Caelum is indeed a recorded word form, although far less frequently used than Caelus.

30 On Saturn extensively Baratte 1997: 1078-1089.

31 Hesiod Theogony, Works and days, Testimonia, edited and translated by Glenn W. Most, Hesiod 1, Cambridge.

32 In contrast to the personifications Saeculum and Caelum, the figure of Chaos has, as far as I know, hardly been dealt with so far. As already noted, Blanco Freijeiro embeds Chaos in the orphic contex and identifies him as the son of Saeculum (Chronos). Alföldi 1979: 4 briefly goes into the description from the Theogony of Hesiod and refers to Chaos as the dark figure of the confusion of the primeval beginnings.

33 The remarkable parallel to the iconography of Atlas has already been noticed by many scholars but has not been further analysed yet (Blanco Freijeiro 1971: 160; Quet 1981: 106-107; Díez de Velasco 1994: 425). On Atlas extensively: De Griño et al. 1986: 2-16; Scheer 1997: 217-218. For iconographic comparisons see for example Atlas Farnese from Rome, Museo Archeologico Nazionale Naples, 6374 (copy of the $2^{\text {nd }}$ century AD after a Hellenistic original) (Cappelli - Lo Monaco 2010: 28). 


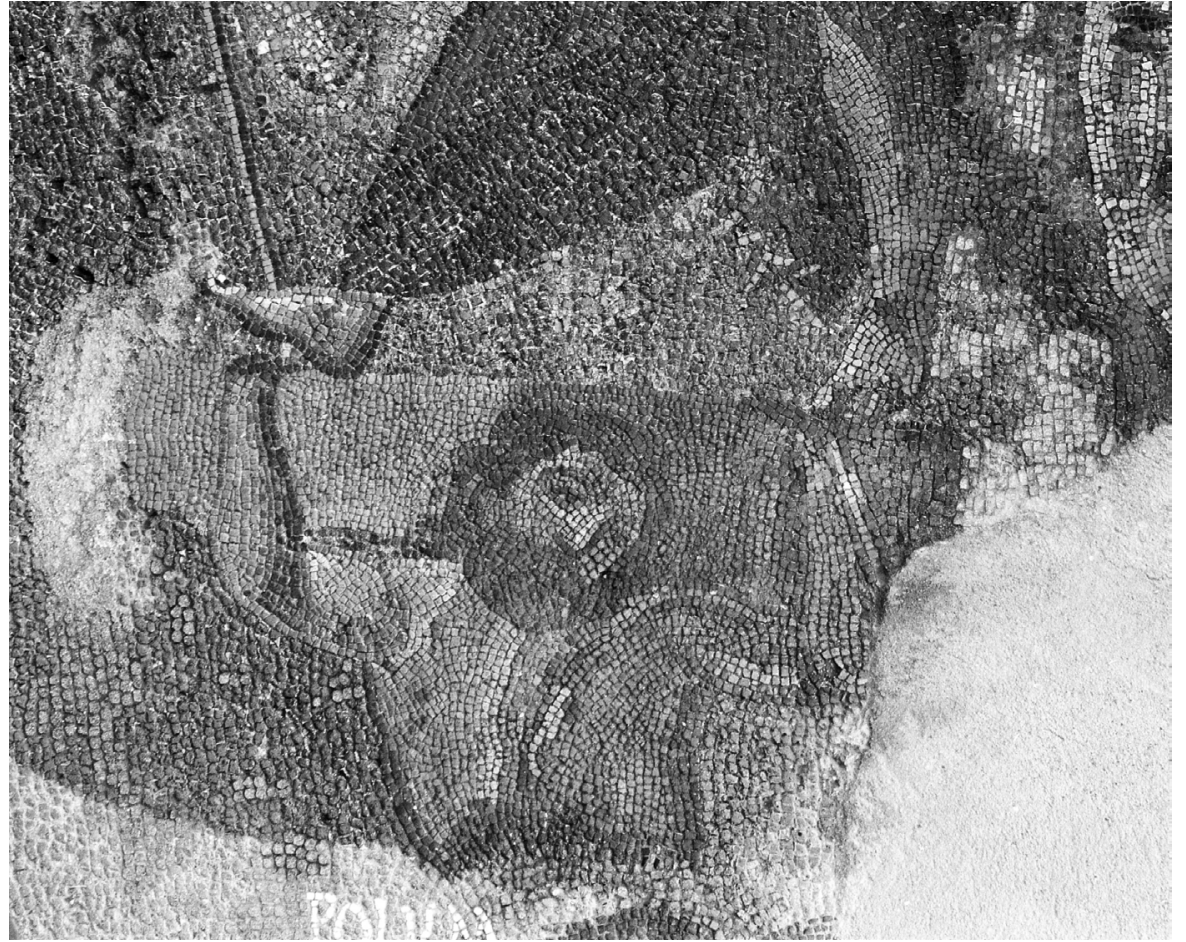

Image and inscription share a semantic overlap. Both Polum and Atlas embody similar geographic or astronomic phenomena: the first carries the celestial sphere, the latter embodies the pole ${ }^{34}$. Since no iconographic comparisons are known for Polum, this shared sematic field might have facilitated the identification for the viewer.

\section{Interim Conclusion}

The four introduced personifications feature four different strategies on how the respective intended statement was conveyed.

In the case of Saeculum, one could speak of a double generalisation. The term Saeculum as designation of a personification for once appears here without the particularising epithets frugiferum or aureum. Although the figure's way of representation on the cosmological mosaic draws back on the iconography of Saeculum Frugiferum to a certain extent, it borrows it only in such a reduced manner that it is no longer specific. The alternatively provided attributes sceptre and diadem are worn by a variety of mythological figures and therefore do not serve to further specify the depiction. Image and writing are here used in a generalising way, whereby the personification is restored to its basic meaning. Therefore, it is apparently supposed to mean not a saeculum of a specific quality but the timespan as such.

In the case of the personification Caelum, there are several iconographic comparisons which follow a determined iconographic convention. On the cosmological mosaic, the common pictorial scheme has almost been reversed: Caelum appears beardless instead of bearded, relaxing on a throne instead of holding the celestial sphere above him and instead of the characteristic cloak spanned above his head, his attribute is a simple vegetal wreath. Thereby, the way of representation of Caelum is downright alienated; without the inscription, the personification could not be identified.

34 Polus is probably to be understood as the Roman pendant of the Greek Titan Koios (Hyg. praef. 10 fab. 140, 2; Scherling 1951: 1424; Díez de Velasco 1994: 425).
Figure 12

Detail of the personification Polum on the cosmological mosaic. (C) Deutsches Archäologisches Institut Madrid, D-DAIMAD-WIT-R-105-78-15, Photo: Peter Witte (Detail) 
Concerning the two figures Chaos and Polum, the strategy is a similar one. For both personifications, new pictorial creations seem to be used. In the case of Chaos, the iconography was based on the one of Saturn/Kronos. Thereby, the viewer cannot immediately grasp the connection of Saturn/Kronos (image) and Chaos (inscription). Whereas both deities are connected to temporal phenomena, they embody totally different aspects of time. With Polum, the specific drawing on the representation of the semantically closely connoted Atlas makes sense both regarding content and in a narrative way ${ }^{35}$. Both are embodiments of geographic/astronomic phenomena. The Titan Atlas is above all connected to carrying the celestial sphere, while Polum on the mosaic in Mérida supports the platform on which the god of the sky sits enthroned in the middle. In contrast to Chaos, Polum became more easily identifiable through the orientation towards the iconography of Atlas.

This orientation towards familiar motives or the iconography of well-known mythological figures, which can be observed in all four personifications discussed, is not to be seen as a mere help to identification. Since both the way of representation and the inscriptions evoke different associations in the viewer, the depictions of Saeculum, Caelum, Chaos and Polum become more complex and multifaceted. It is notable that these personifications function on two levels and that the different references were combined in a totally new constellation. Provided that one was supposed to proceed from the level of images, one associates the personifications with an unspecific father god (Saeculum), a deity sitting relaxed on a throne reminding of Dionysos (Caelum), Saturn/Kronos (Chaos) and Atlas (Polum). Such a combination of these figures has so far been unknown. It is the same if one proceeds from the inscriptions - this combination of Saeculum, Caelum, Chaos and Polum seems to be unique.

Only after the identification of the personifications and their respective references which they possess due to the interaction of image and writing, it becomes clear that the mosaicist indeed adverts to already familiar associations. In the case of Saeculum, it is made evident that it is a matter of the basic meaning and not of a specific epiclesis by the adoption of a generalising father god iconography. The combination of the sky god and Polum/Atlas was easy to decode for the viewer, since Atlas carried the celestial sphere on his shoulders. Also, the connection of Saturn/Kronos to the sky god was not new, for they are father and son and especially known for Caelus'/Ouranos' emasculation by his son Saturn/Kronos (Hes. theog. 175-182).

Even if these different associations are evoked in the viewer, they are not the sole intended meaning but are rather only a nuance of the meaning of the respective personification. This becomes evident through the fact that, for example, the iconography of Atlas and Saturn/Kronos is taken up, but the associations explicitly do not refer to their names but designate Polum and Chaos. Perhaps it is for this reason that the way of representation of Caelum is set off so clearly from the usual iconography of the sky god because its neighbouring personification Chaos iconographically adverts to the deity Saturn/Kronos and can therefore also be associated with this figure to a certain extent. Through the visual differentiation, possible negative connotations connected to the father/son relationship of Caelus/Ouranos with Saturn/Kronos were to be avoided.

The composition of the celestial group is T-shaped. It is noticeable that

35 On the recourse to the iconography of established and semantically close mythological figures see Shapiro 1986: 5-6; Meyer 2007: 184-186, 202. 
the personifications Polum (respectively Atlas) and Caelum both embody geographic/astronomic phenomena. They are surrounded by three different concepts of time: Saeculum indicates a time span of 100 or 110 years which string together cyclically. Chaos is the primordial state and Saturn/Kronos, who can be associatively connected to Chaos on the mosaic, represents an ideal time long gone.

\section{Conclusion}

On the basis of the figures of the celestial group it could be demonstrated how variably image and inscriptions on the cosmological mosaic could be combined with each other by generalisation and specification. In the four personifications discussed, four different modes of putting image and inscription into relation could be detected. Both factors - way of representation and inscriptions - explain each other and are therefore both essential for the decoding of the intended statements. The different multifaceted associations with other mythological figures which were evoked by the iconography or by the inscriptions make the identification and interpretation of the personifications very demanding for the viewer. Due to the evoked associations, the mosaic on the one hand features completely new references and a new combination of figures. On the other hand, it plays with established references and connotes to the viewer that these established references were modified here.

This contribution could only touch on how sophisticatedly iconography and inscriptions were put into relation to each other and which impact the interplay of both factors has on the discussed personifications. It is possible to build on the basis of these examinations in the future and to develop an interpretation of the celestial group or respectively of the complete pictorial work. 


\section{Bibliography - Kaynaklar}

Alföldi 1979

Alföldi-Rosenbaum 1979

Alföldi-Rosenbaum 1993

Arce 1996

Baratte 1997

Baudy 1999

Beltrán Lloris et al. 2017

Blanco Freijeiro 1971

Blázquez 1993

Bonacasa Sáez 2014

Borg 2002

Cappelli - Lo Monaco 2010

Corpus España I

Cruz Fernández Castro 1986

Davis 2000

De Griño et al. 1986

Díez de Velasco 1994

Driss 1966

Dunbabin 1999

Elsner 1996

Fernández-Galiano 1990

García Sandoval 1969

Giuliani 2003

Gómez Pallarès 2011

Heckel 2002

Hernández Iñiguez 1986a

Hernández Iñiguez 1986b

Honikel (in print)

Huld-Zetsche 1986

Kirk 1994

Lancha 1983
A. Alföldi, "Das kosmologische Bild des Bodenmosaiks von Mérida", A. Alföldi (ed.), Aion in Mérida und Aphrodisias, MB 6, Mainz, 1-12.

E. Alföldi-Rosenbaum, "Technische und stilistische Beobachtungen zum kosmologischen Mosaik von Mérida und seiner Umrahmung”, A. Alföldi (ed.), Aion in Mérida und Aphrodisias, MB 6, Mainz, 26-34.

E. Alföldi-Rosenbaum, "Mérida revisited. The cosmological Mosaic in the Light of Discussions since 1979", MM 34, 254-274.

J. Arce, "El mosaico cosmológico de Augusta Emerita y la dionisyaca de Nonno de Panopolis”, CE 12, 93-116.

F. Baratte, "Saturnus", LIMC VIII, 1078-1089.

G. Baudy, "Kronos”, DNP 6, 864-870.

F. Beltrán Lloris - B. Díaz Ariño - M. J. Estarán Tolosa - C. Jordán Cólera - A. Klöckner - Th. G. Schattner (eds.), Bild und Schrift, Medienkombinationen in den eisenzeitlichen Kulturen Hipaniens, Kolloquium zum Ehren von Jürgen Untermann = Imagen y escritura. Medios de comunicación combinados en las culturas de la Edad del Hierro en Hispania, Coloquio en honor de Jürgen Untermann, Actas del XII Coloquio internacional de lenguas y culturas paleohispánicas Giessen, Palaeohispanica 17, Zaragoza.

A. Blanco Freijeiro, "El mosaico de Mérida con la alegoría del saeculum aureum”, J. Alsina (ed.), Estudios sobre el mundo helenístico, Sevilla, 153-178.

J. M. Blázquez, Mosaicos romanos de España, Madrid.

S. Bonacasa Sáez, "La pervivencia de la iconografía de Ba'al Hammon en época romana: El caso de Saeculum Frugiferum”, J. M. Álvarez - T. Nogales - I. Roda (eds.), Centro y periferia en el mundo clásico, Actas XVIII Congreso Internacional de Arqueología Clásica $=$ Centre and periphery in the ancient world, Proceedings XIII ${ }^{\text {th }}$ International Congress of Classical Archaeology, Mérida, 455-457.

B. Borg, Der Logos des Mythos, Allegorien und Personifikationen in der frühen griechischen Kunst, Munich.

R. Capelli - A. Lo Monaco, The National archaeological museum of Naples, Naples.

A. Blanco Freijeiro, Corpus de mosaicos de España I, Mosaicos romanos de Mérida, Madrid, 1978.

M. Cruz Fernández Castro, "Chaos”, LIMC III, 188-189.

J. M. Davis, "The Search for the Origins of the Villa of the Mysteries Frieze”, E. K. Gazda (ed.), The Villa of the Mysteries in Pompeii, Ancient ritual, modern muse, Ann Arbor, 83-95.

B. De Griño - R. Olmos - J. Arce - L. J. Balmaseda, “Atlas”, LIMC III, 2-16.

F. Díez de Velasco, "Polos", LIMC VII, 425.

A. Driss, Die Schätze des Nationalmuseums in Bardo, Sammlung Kunst und Geschichte 1, Tunis.

K. M. D. Dunbabin, Mosaics of the Greek and Roman World, Cambridge.

J. Elsner (ed.), Art and text in Roman culture, Cambridge Studies in New Art History and Criticism, Cambridge.

D. Fernández-Galiano, “Observaciones sobre el mosaico de Mérida con la Eternidad y el Cosmos", Anas 2/3, 173-182.

E. García Sandoval, "El mosaico cosmogónico de Mérida”, BSAA 34, 9-29.

L. Giuliani, Bild und Mythos, Geschichte der Bilderzählung in der griechischen Kunst, Munich.

J. Gómez Pallarès, “L'Écriture qu'on foule. Inscriptions sur mosaïque dans les espaces privés d'Hispania”, A. M. Corbier - J.-P. Guilhembet (eds.), L'Écriture dans la maison romaine, Paris, 263-278.

H. Heckel, “Zeitalter”, DNP 12, 2, 706-709.

M. Hernández Iñiguez, “Copia”, LIMC III, 304.

M. Hernández Iñiguez, “Copiae”, LIMC III, 305.

A.-L. Honikel, "Mérida re-revisited. Neue Untersuchungen zu dem sog. kosmologischen Mosaik in Mérida", MM 62, Wiesbaden.

I. Huld-Zetsche, Mithras in Nida-Heddernheim. Gesamtkatalog, Archäologische Reihe 6, Frankfurt a. M..

G. S. Kirk, Die vorsokratischen Philosophen, Einführung, Texte und Kommentare, Stuttgart.

J. Lancha, "La mosaïque cosmologique de Mérida. Étude technique et stylistique”, MelCasaVelazquez 19, 17-68. 
Le Glay 1981

López Monteagudo 1997

Mayer 2004

Meyer 2007

Montiel Alvarez 2015

Müller 2019

Musso 1983/4

Newby - Leader-Newby 2007

Notermans 2007

Quet 1981

Rutter - Sparkes 2000

Şahin 2009

Scheer 1997

Scherling 1951

Schmieder (in print)

Shapiro 1986

Sichtermann 1992

Sichtermann - Koch 1975

Squire 2009

Tam Tinh 1994

Thiemann 1959

Weil 2005

Wünsche 2005
M. Le Glay, “Aion”, LIMC I, 399-411.

G. López Monteagudo, “Saeculum”, LIMC VIII, 1071-1073.

M. Mayer, "Las inscripciones de los mosaicos de la villa de Carranque (Toledo, España)", Musiva \& Sectilia $1,110-125$.

M. Meyer, "Wunschbilder. Zu bildlichen Darstellungen abstrakter Personifikationen des guten Lebens”, B. Groneberg (ed.), Die Welt der Götterbilder, Beihefte zur Zeitschrift für die alttestamentliche Wissenschaft 376, Berlin, 183-205.

T. Montiel Alvarez, "Estudio iconográfico de la coraza de Augusto de Prima Porta", ArtyHum 18, 125-134.

F. G. J. M. Müller, The Aldobrandini wedding, Iconological studies in Roman art 3, Amsterdam.

L. Musso, Manifattura suntuaria e committenza pagana nella Roma del IV secolo. Indagine sulla lanx di Parabiago, Studi e materiali del Museo della civiltà romana 10, Rome.

. Newby - R. E. Leader-Newby (eds.), Art and Inscriptions in the Ancient World, Cambridge.

A. Notermans, Sprekende mozaïeken. Functie en betekenis van teksten op Romeinse vloermozaïeken, Nijmegen.

M.-H. Quet, La mosaïque cosmologique de Mérida, Paris.

N. K. Rutter - B. A. Sparkes (eds.), Word and image in ancient Greece, Edinburgh Leventis Studies 1, Edinburgh.

D. Şahin, "The Zodiac in ancient Mosaics. Representation of Concept of Time”, JMR 3, 95-111.

T. Scheer, “Atlas”, DNP II, 217-218.

K. Scherling, "Polos”, RE XXI, 1424.

C. Schmieder, Bild und Text auf römischen Mosaiken. Modi und Funktionen intermedialer Konfigurationen im Kontext der Wohnkultur des 3.-5. Jahrhunderts, Materiale Textkulturen, Heidelberg.

A. Shapiro, "The Origins of Allegory in Greek Art", Boreas 9, 4-23.

H. Sichtermann, Die mythologischen Sarkophage 2, Apollon, Ares, Bellerophon, Daidalos, Endymion, Ganymed, Giganten, Grazien, ASR 12, 2, Berlin.

H. Sichtermann - G. Koch, Griechische Mythen auf römischen Sarkophagen, Bilderhefte des Deutschen Archäologischen Instituts Rom 5/6, Tübingen.

M. Squire, Image and Text in Graeco-Roman antiquity, Cambridge.

T. Tam Tinh, “Ouranos”, LIMC VII, 132-136.

E. Thiemann, Hellenistische Vatergottheiten: das Bild des bärtigen Gottes in der nachklassischen Kunst, Orbis antiquus 14, Münster.

J. Weil, "Personifikationen. Medium kaiserlicher Selbstdarstellung”, A. Geyer (ed.), Moneta Augusti, Römische Münzen der Kaiserzeit und der Spätantike im akademischen Münzkabinett der Friedrich-SchillerUniversität Jena, Ausstellungskatalog Jena, Jenaer Hefte zur Klassischen Archäologie 6, Jena, 79-86.

R. Wünsche, Glyptothek München, Meisterwerke griechischer und römischer Skulptur, Munich. 